\title{
Using Theatre as a Research Tool: Troubleshooting and Benchmarking Pakistan's Devolution Plan ${ }^{1}$
}

\section{Shahrukh Rafi Khan and Aasim Sajjad Akhtar"}

\section{Background and Objective}

One of the most key initiatives of the military government that assumed power in Pakistan in October 1999 is devolving power to the grassroots level. ${ }^{2}$ The elections for the lower three tiers, (Union, Tehsil and District) have taken place as has the elections for the pivotal post of the District Nazim (governor). Notwithstanding expressed reservations about the suspension of democracy, many civil society groups and donors, who had been advocating devolution or decentralisation in the past, hoped for the success of this initiative as one possible way for making effective the delivery of public service to the grassroots level. While others have undertaken benchmarking exercises to evaluate this initiative, it was thought that using theatre as a tool would be a unique method for complementing these other initiatives. ${ }^{3}$

Thus the goal of this particular exercise was to use theatre as a tool to identify where bottlenecks and problems in service delivery and dispensation

\footnotetext{
*The authors are Executive Director, SDPI, and Coordinator, Advocacy, SDPI, respectively.

1 Feedback from Dr. Glyn Berry of DFAIT (Department of Foreign Affairs and International Trade) at the conceptual stage and financial support from DFAIT is gratefully acknowledged, as are the helpful comments in Farzana Bari's peer review for the SDPI working paper series. In addition, this exercise would not have been possible without the field support of The Asia Foundation Supported DRCEP (Democratic Rights and Citizen's Education Program) partners including the Institute of Development Studies and Practice, (IDSP) in Balochistan, Sungi Development Foundation in the NWFP, South Asia Partnership (SAP) in the Punjab and Pakistan Institute of Labour Education and Research (PILER) in Sindh. Naturally, the role of the theatre group, Interactive Resource Centre (IRC), was pivotal. Rashida Dohad of TAF and Waseem Mohammad and Mohammad Tariq of IRC deserve special mention in respectively helping with the organisation meetings, providing feedback and in very creatively conceiving the theatre skits tailored to the particular locality.

${ }^{2}$ For a detailed analysis and critique of the government's devolution plan refer to Khan (2001).

${ }^{3}$ In this regard, all the numerous evaluations of the government's social action plan and research on the social sector service delivery prior to instituting local government institutions on August 14, 2001, could be viewed as benchmarks. More targeted exercises include the NRB's video documentary, a UNDP/CIDA supported study in several districts, a DFID supported poverty appraisal, a World Bank study conducted by P1DE (Pakistan Institute of Development Economics) and SDPI for the Bank's poverty appraisal and a UNDP supported study on the dispensation of justice by SDPI. The DFID and Bank study are also extensively reviewing the state of social sector service delivery.
} 
of justice arise under the current system and to solicit feedback on how things may be improved in the future. As the government works towards improving the local government law, on the basis of which rules of business are framed, it was anticipated that timely feedback would be valuable. ${ }^{4}$

While, as indicated above, much benchmarking activity is underway, none of this is actually focused on soliciting feedback on how things could be improved. In this regard, the use of theatre provides a unique opportunity to draw out and solicit feedback from the stakeholders. We thought that this report would complement other sources on the current situation, but also go beyond them in providing suggestions to policy makers on how things should and should not be done in the future.

In general, the objectives of this exercise were to get insights into the shortcomings of the existing system from a grassroots perspective and use those to provide suggestions for improvement. More specifically, we hoped to find out how local bodies' powers, bureaucratic accountability and allocation of fiscal resources should be improved, as perceived at the grassroots level. In addition, we planned to access the training needs of elected local government representatives in the new operating environment. Finally, we planned to get insights into the problems of specific groups such as women and the very poor.

Another way of stating our objective in a broad sense was that we hoped to have an impact on the formulation and revision of local government rules of business, based on findings reported, and hence on the welfare and quality of life of the majority of Pakistan's population. In the second section of this paper, we outline the method used. In the third section, we critically evaluate the use of theatre as a research tool and in the fourth section, we provide a brief outline of the theatre skits. In the fifth section, we summarise the process and report the findings based on the theatre exercises and we end with a summary and recommendations.

\section{Method and Concept}

The following two specific cases were selected for developing theatre skits around:

i. Delivery of public schooling at the grassroots level.

ii. Handling of a public safety case of village women reporting sexual harassment.

\footnotetext{
${ }^{4}$ Government of Pakistan, 2001.
} 
The reason for this selection was that it would address public service issues, for the most marginalised, both for social sector delivery as well as for the dispensation of justice. Theatre skits were developed to depict public service delivery pre-devolution. The idea was to be balanced but provocative enough to generate a discussion. The skits were altered to suit each specific location.

The urban and rural union councils were selected in each province based on contacts. Each skit was followed by a discussion skilfully guided by a facilitator to solicit feedback. The stakeholders for the schooling discussion were citizens, elected union or Tehsil Councilors, teachers and members of the education administration. For the discussion on justice, an attempt was made to include lawyers and district level police officers.

Conceptually, the commonality in the two cases is that we were dealing with a power issue. In education, it is the power of teachers relative to parents, communities, and the education establishment. In the sexual harassment case, it is the lack of power of the poor relative to the large landlord and district justice establishment. This imbalance of power as a source of problem in local governance is the conceptual framework that earlier research suggested to us. ${ }^{5}$ Hence we sought confirmation for this in the pretest and having confirmed its value, cast our findings in this framework.

We focused on the union council level because, institutionally, that is as close as the devolution plan gets to the grassroots level.

\section{Use of Theater as a Research Tool}

Theatre was used as a tool to ascertain how well the devolution plan was working in practice. Initially, the use of theatre was meant to simply present a situation on which to build a discussion. However, in the testing phase, it became apparent that the qualitative responses, that a visual performance generated, were substantive and richer than those that otherwise might have been generated from a focus group discussion (FGD). Hence, we began to view theatre as a research tool because of the detailed observations and analysis that it induced based on participant discussions.

Thus, we view this research methodology is an extension of the focus group technique. In addition to generating qualitative information beyond the scope of a FGD, the use of theatre had a great awareness-raising impact. It enhanced the understanding of the participants concerning the research goal and therefore the theatre induced, as mentioned above, very rich feedback.

\footnotetext{
${ }^{5}$ Khan (2001).
} 
For example, the depiction of a rape or honour killing in the skits on dispensation of justice facilitated a discussion on the issues that might not otherwise have been possible. The skit broke the ice and immediately enabled the facilitator to launch into a discussion. Without the assistance of a skit, it would have been very difficult to broach the subject in mixed company in very conservative localities.

While there is much that was positive in the use of theatre as a research tool, there are limitations in common with those of the FGD method and even beyond that. Quantitative social scientists view qualitative research methods, due to the limited sampling, as generating hypothesis rather than conclusive findings. This technique would be open to the same criticism, although, in our view, the commonality of findings across all regions and provinces suggests to us that the findings are substantive and, as such, should be taken seriously by policy makers. A limitation more specific to theatre is that the richer expense is derived from a more expensive research tool and hence the sample may need to be even more restricted than the usual qualitative research methods. Given the expense, we would only recommend it for research issues of a very delicate nature for which the more conventional FGD may not be suitable.

Finally, our research here, as elsewhere, shows that researchers may be prone to romanticising the wisdom and sound ideas and suggestions that are likely to emerge from grassroots level research. Our discussion sessions were rich in findings about what was going wrong in the past, the chaos of the interim period between two administrative systems and in identifying structural problems and systemic needs, but poor in concrete suggestions about what could be done.

\section{Theatre Skits}

As earlier indicated, two theatre skits were developed to explore social sector service delivery and the dispensation of justice. The focus was to use the skits to provoke discussion among stakeholders on problems, explore how were they dealt with in the past, discover what stakeholders expect would happen under the new devolved system and solicit their recommendations. Both the skits were modeled on real events.

\section{Education Skit}

This skit starts with a classroom scene in which a teacher is seen disciplining, or rather, abusing all the students except for the son of the local influential. He beats them excessively, humiliates them, and sends the girls to his home to help with his housework. A friend visits, warning him 
not to be too harsh since he might get reported. He laughs this off telling his friend that he has worked hard to develop a close relationship with the local influential. Thus, he claims that he now has the political backing to do as he pleases. Also, he points out, that with the low salary he gets, he has no incentive to be conscientious and professional anyway.

In the next scene, one of the boys who got beaten complains at home to his grandmother. She is aghast at how much he has been beaten and vows to take him out of school. She says he is better off learning how to be a mechanic or something similar. The father, mother and sister all proffer a variety of comments, including that he must have been beaten because he didn't do his work. Eventually, the newly elected councilor happens to drop by, and the grandmother tells him of the teacher's brutality. The councilor vows to take the case up saying that no teacher should beat a child so badly.

The final scene is again in the classroom, and it is much the same as the first scene in spirit. The teacher is asleep and the students are enacting various punishments he has meted out to them.

\section{Sexual Harassment ${ }^{6}$}

The first scene is a typical village household scene. The husband and wife sit down to have a discussion on a problem they are facing with regard to their small piece of land, which is fully enclosed in the land owned by a big landlord and in adjoining land that this landlord is acquiring. The family is concerned about pressure from the wadera (landlord) regarding selling their small piece of land also.

In the next scene, they go to meet the newly elected councilor to tell him of the tricky situation they are confronting. The councilor promises to meet with the landlord and persuade him not to force this family to sell their land. The father comes home relieved that the landlord will not capture his land. However, in the same scene, the family realises that one of the girls is late in returning from the village well, where she has gone to fetch water. As the concern grows, they hear sharp cries -- the landlord's goon has raped the girl.

\section{Honour Killing (Mardan)}

The skit starts with a household scene in which the husband and wife are concerned about the impending wedding of their daughter to her

\footnotetext{
${ }^{6}$ This was the skit prepared for Gujrat, Hyderabad and Guzdar. Honour killing is more common in Mardan and that skit is described in 3.3.
} 
Uncle's son. They feel that the nephew is not a good match, since he is involved in drugs and other unpalatable activities. However, the Uncle is an influential man, and they are afraid about how to tell him that they don't want the wedding to go ahead. The cousin wedding had been agreed to at the birth of the girl. However, the son of a family friend is an alternative prospect for their daughter. They decide to ask the newly elected councilor for advice and help.

In the next scene, while they are having a discussion with the councilor, the Uncle shows up. They explain the situation to him and he seems to have a fairly reasonable response to his younger brother's concern for his daughter's welfare. He warns them that his son has a volatile temperament, but, nonetheless, assures them that he will persuade his son to call off the marriage.

The final scene is again in the prospective bride's home where preparations for the alternative match are underway. Suddenly, someone in the family realises that the daughter has not come home from school. They cannot find her despite checking everywhere. Finally, a friend enters the house frantically and informs them that the nephew shot their daughter to safeguard his "honour."

After each skit, the facilitator initiated and managed a discussion, ensuring the participation of almost everyone present. This revealed the stakeholders understanding of the current system and its ability to deliver in a speedy and efficient manner. The problems that emerged and the feedback for improvements were documented and are reported on in the next section.

\section{Findings}

\section{Union Council, Chiriawala (Rural), Gujrat District, Punjab ${ }^{7}$}

The location for the skit presentation and discussion was a local government school. The profile of the participants was reasonably varied. There were teachers, doctors, lawyers and ordinary citizens present. About eight elected union councilors (DC) from the local DC were present. including the nazim, and officials of the education department were also present. Police officials and representatives of the local magistracy were invited but did not attend. In all, about 40 people were present.

The skits and discussion was not allowed to go ahead by the Nazim of the local union council, who interrupted the proceedings just as they

\footnotetext{
${ }^{7}$ Fieldwork conducted on August 4, 2001.
} 
were getting underway. He claimed that he had been misled and that the event was not true to the way it had been described to him when he agreed to attend. He made rude remarks about the local organisers and their 'impure' intentions. Finally, he told the rest of the gathering to disperse immediately. When requested to at least listen to the organisers and guests, he started to issue verbal threats to the local organisers, and eventually, the gathering broke up.

In the immediate aftermath of the incident, it was thought that it might be better for the local organisers if the field team departed immediately to avoid any future confrontation. However, upon discussion, it was decided that it would be a show of solidarity with the local organisers if the group remained intact at the location of the incident for a while. Subsequently, everyone went back to Kharian town to discuss what had transpired.

A number of problems were identified including that not enough officials, particularly police officials, of the administration were present. The Assistant Education Officer (AEO) was present, and she was quite supportive of the initiative, and even asked the nazim to be patient when he had his initial outburst. The absence of the police officials irritated the nazim because he clearly wanted to use this opportunity to meet with them. It was also established that the nazim was from an influential background and was likely to have been displeased not being accorded a special seating status in the gathering. There was also mention that women from his chaudbury clan were sitting together with kammi ("untouchable"caste) women, and that this was not generally acceptable to the influentials. There was talk that the nazim had objected to the un-Islamic (mixed) nature of the gathering. However, since women from his clan did voluntarily attend, this was probably an excuse for his real misgivings.

The unexpected turn of events provided a good learning opportunity. It highlighted that the elite of the area still have significant say in local affairs and that one election is not likely to change this or change deeply entrenched modes of behaviours and attitudes. Indeed, it was apparent that all the councilors present were part of a panel because not one of them disputed the decision of the Nazim to walk out. Local community members informed us that the area surrounding Chiriawala is known for violence and feuds between rival influentials. The attitude of the nazim was very uncompromising and authoritarian.

The prospect of such a person being the ultimate authority in the area was quite unsettling, and brought home again that far reaching reform, such as land reform, to create a more level playing field should accompany 
devolution if it is to be successful. It also showed that with such leadership, in practice, there is likely to be little change in the way services are provided and justice is meted out.

The Nazim's outburst was unexpected and a warning about the possible behaviour of elected Councilors. As the system puts much faith in these elected representatives (new faces) being change agents, when this premise proves false, the entire devolution exercise becomes questionable. Another lesson learned from the experience was that local organisations are unlikely to be accorded any importance or respect by the administration and the police, and therefore the provincial and national partners should issue invitations and explanation of the objectives of the gathering. It was also decided that the Minister for Local Government should be informed about the initiative and asked to send out requests to the various officials to be involved in the exercise to cooperate.

\section{Union Council 54 (Urban), Gujrat District, Punjab ${ }^{8}$}

Efforts were made immediately after the incident in rural Gujrat to contact relevant officials to ensure that no problem arose on the following day in Gujrat city. Fortunately, there was no such repeat incident, although once again police officials did not attend. This was despite a confirmation from the SSP (Senior Superintendent of Police) Gujrat that he would send the DSP (Deputy Superintendent of Police) to the exercise.

The location was the Gujrat Press Club and the participant profile was otherwise quite good. Local lawyers, doctors, teachers, the district education coordinator (DEC), and other civil society groups were present. In all, about 45 people attended, and fifteen of them were women and seven were elected Councilors.

The programme started with a brief introduction to the objectives of the exercise and then the first skit was presented about the abusive and negligent teacher in the local government school. The skit was well received, and many people agreed that the situation depicted was very close to reality. Among those who agreed was the DEC, who went on to say that the lack of resources was not the primary constraint to improved education, but rather, the lack of will and commitment on the part of teachers.

The discussion then became a more general debate about development and systemic problems pertaining to that. When the focus was brought back to the actual problem presented and how it was addressed in

\footnotetext{
${ }^{8}$ Fieldwork conducted on August 5, 2001.
} 
the past and how it should be addressed, the councilors were very vocal. They said that they would not allow the practice of abusing children in schools, and would also eliminate absenteeism and improve teaching standards. These broad goals having been shared, the discussion turned to how this would actually take place, with many of the audience skeptical about the ability of the new representatives to bring about a change. The councilors admitted that the only actual information they had been given was that committees were to be formed which would include educationists, other citizens and themselves to monitor the state and functioning of schools in the area. Upon being questioned about how the committees would actually function and how their membership would be determined, it became apparent that the councilors were not informed. A point was made that existing school committees were not operational. The question was also raised as to why one should expect the new committees to be any different.

The issue that arose next was whether the committees and the councilors themselves would actually have authority under the new system to address the sort of problem depicted by the skit. There was again no consensus on this issue, and the DEC himself was unable to identify what his role was in the new set-up. The councilors, however, repeatedly stated that they would attempt to create public consensus on such issues and would work on them regardless of whether the official set-up actually gave them room to take initiatives. The councilors mentioned the role of parents repeatedly, and said that, if nothing else, they could at least interact closely with parents and convince them to become a larger part of their children's school going experience. A number of people pointed out that very few parents took an interest in their children's education, and that this was part of the reason that the quality of education was poor.

The issue of political interference was also raised repeatedly, and it was established that both politicians and bureaucrats were guilty of this in the past. It was pointed out that unless this interference was stopped, there was little chance that there would be any change in how schools operated. Again, the outcome of this discussion was that there was no real clarity on whether councilors would have the power to stop such interference, and also on whether bureaucrats would still have the same kinds of power.

After a break, the second skit was presented. This skit, despite touching a very sensitive issue, was again well received and left the audience quite pensive. The discussion remained very fluid and relaxed, but also very focused. The issue that immediately arose was whether or not, under present circumstances, such a case would even have been reported. Two points were flagged. First that this issue was considered to be taboo at a public level, and, therefore, it was rarely reported. Second, that, even if it was reported, the 
chance that there would be a judgment in favour of the victim were slim because officials, including the police, were often co-opted by influentials.

As soon as these issues were identified, the debate focused on why such incidents were not even reported in the first place. In many ways, it was established that the victim in this case was always likely to face the same constraints to receiving justice regardless of the system in place. Indeed, it was reiterated many times over that this was a societal bias that had to be corrected at all levels before any governance system could even be discussed. In this regard, the role of the press was discussed at length, and it was suggested that the press had often been part of the problem by sensationalising the issue and further alienating the victim and her family. There were some journalists present who claimed that their reporting had been much more progressive, and that they would continue to play a positive role in bringing perpetrators of such crimes to justice.

The Councilors once again admitted that they had no real notion of how to go about addressing this sort of problem in terms of the new system and hierarchies. However, they were adamant that they would definitely take such issues up in earnest and try to ensure that justice was served. One of the councilors concurred with the opinion that this was an issue that exposed society's overall biased attitudes, and that addressing this was the most important long-term step that was needed. They also pointed out that much time would need to be spent with the victim and her family to assure them that they should take up the case. The councilors said they were committed to resolving a case like this in cooperation with the police and administration, but this statement seemed like lip service.

A citizen in the audience opined that, in cases such as these, concerned citizens needed to come together to mobilise public opinion. The councilors were even encouraged to organise rallies to highlight the issue, in a sensitive manner naturally, so that the social taboo could be challenged. It again seemed that the councilors simply agreed with this suggestion without really offering any idea of how they would tackle the problem. It seems clear that the councilors' are as yet unsure about what powers they will actually be able to exercise and therefore their comments were largely hypothetical and based on what they would like to do rather than what they will be able to do. The discussion concluded with an acknowledgement that, on issues such as these, a fundamental change in people's psyche was primary. The debate about whether the new system would improve the dispensation of justice in such a situation was more or less an aside. The absence of the police made it difficult to say what the 
dynamic would be between the new councilors and the police when such incidents took place.

\section{Union Council 9 (Urban), Hyderabad District, Sindh'}

As in Gujrat, the administration did not show up despite being sent a letter from the Federal Minister for Local Government and Rural Development requesting support for the exercise. Elected Councilors from several urban Hyderabad union councils were present, not just those of UC 9. The attendance otherwise was reasonable, with journalists, schoolteachers, lawyers, social activists, and development workers all represented. There were a total of about 40 people present. The poor turnout of the local administration and Councilors was partially attributed to Councilor oath-taking ceremonies taking place that day. Nevertheless, the local partners had clearly not done an adequate job in mobilising participants.

That said, the discussion among those present was quite lively and raised a number of good points. All, including the councilors, participated in the discussion of the first issue of the abusive and negligent teacher. Everyone stressed the negative effects of political interference, and suggested that this was the main impediment to improving the quality of teachers, and therefore education in government schools. In particular, it was pointed out that there was virtually no way of ensuring that teachers were disciplined or that their standard was improved. There was a general consensus that until now, whenever such incidents took place, parents had attempted to take matters into their own hands and had confronted the teacher directly. While this practice was condemned, it was also acknowledged that parents did not want to meet with the administration, because they felt, based on past experience, that this was pointless.

The Naib Nazim of UC 9 suggested that all such affairs should be decided within the school itself, and therefore the parent-teacher-principal relationship should be strengthened. This was a clear rejection of the role of the bureaucracy in the running of schools, which reflected the strained relationship between citizens and the state. There was also little indication that the councilors had any notion of working with the education department to improve matters. They repeatedly stated that school affairs should be settled within the school itself.

The discussion also focused on the limited role of parents in their children's education-the parent-teacher associations and other such groups were criticised for being inept. Indeed, it was even pointed out that parents

\footnotetext{
${ }^{9}$ Fieldwork conducted on August 12, 2001.
} 
themselves abused their children for irritating teachers. The councilors admitted that their primary role in improving this situation would be to interact with parents, teachers, and principals. However, as in Gujrat, the actual role of councilors within the new system, the powers that they would be able to exercise, and the means of addressing such problems were not clear to the councilors themselves. They pointed out that there had been no knowledge of how committees would operate to redress such problems. This lack of knowledge seems to be the biggest problem facing the new councilors, as well as ordinary citizens who are skeptical about the ability of the new system to deliver change.

The skit about the sexual harassment of a local girl by the wadera generated a lot of discussion along the same lines as in Gujrat. The predominant issue once again seemed to be whether or not social custom in the area would permit open investigation of such a case. Indeed, on this occasion, there was even less of a sense that councilors or any new system would induce any change. One suggestion was that women councilors should take such issues up both with the family concerned and with higher authorities. Some of the women councilors were very committed to raising such issues but flagged the important point again that they were unaware of the extent of their powers and how they were supposed to interact with entities such as the police and administration. They stressed the importance of councilors being united so that they could together combat the resistance they might face. Indeed, one women councilor said that her first instinct would be to worry about her own safety because of the potential danger arising from challenging a local influential. The point was also made that this should not only be the responsibility of women councilors but that the male councilors should be just as vocal. In fact, men taking up such an issue might actually carry more weight.

The role of the press was again discussed in this regard. There was a heated debate about whether the press actually played a positive or negative role in highlighting such incidents. It was established that the local Sindhi press was more progressive than the Urdu press. Many journalists present offered their services to councilors and citizens in bringing such injustices to the fore and generating pressure for action to be taken. This was consistent with the view expressed that councilors and civil society in general needed to come together to address such issues. Many of those present actually suggested that events such as this one be taken to communities, and theatre, in particular, be used to highlight the issues. They felt that this could become part of a larger awareness-building campaign that was needed to combat the problem of sexual harassment. 
The absence of the police made the discussion quite one-sided. There was a consensus among those present that the police had never played a positive role in such cases, and was also not likely to start doing so now. When asked whether they would cooperate with the police, the Councilors, as in Gujrat, were not too convincing, even though they claimed that they would attempt to work with the police. There was also a brief mention of legal recourse. However, it was agreed that the court system did not offer much promise and that this would defeat the purpose of devolution in which the solutions were to be identified and resolved at the local level. Overall, the discussion again highlighted that this issue is more about a general societal attitude rather than a system that does not offer justice. If the taboo can be challenged, so can the systemic constraints.

\section{Union Council 4 (Rural), Hyderabad District, Sindh ${ }^{10}$}

The turnout for this session was quite bad. While the District Education Officer (DEO) for Primary Education was present, there was only one councilor from UC 4 present. Once again, the excuse given was that oath-taking ceremonies for councilors were taking place. Otherwise, there was a decent representation of civil society, although there were only three women present, and they did not offer their opinion during the discussion. About 25 people attended the session.

The discussion after the first skit was quite similar to the discussion the day before, with the primary emphasis on the role of teachers and political interference. However, on this occasion, a number of schoolteachers themselves were very vocal, and became defensive on a number of occasions. They emphasised the lack of respect that society accords a teacher, and the impact that this has on the teacher's own commitment and performance. The schoolteachers also pointed out that parents were generally unconcerned about their children's education and that it was important for this to change. The PTAs were constantly referred to as a vehicle to improve the quality of education, and the councilors were encouraged to work with PTAs to tackle problems such as the one presented in the skit.

As expected, the only councilor present said he had no notion of how the new set-up would function and the means through which he or his fellow councilors would address a problem such as the one presented. He asserted that he would take up such issues, but was not clear how effective he could be. There was a great deal of criticism targeted at the DEO and the administration in general including accusations of corruption, made by

${ }^{10}$ Fieldwork conducted on August 13,2001 
some schoolteachers. We learnt that the DEO even warned the person who made the remarks that he would have him fired. The DEO himself claimed that the problem was multi-faceted, and included problems of maintaining teacher standards involving parents, and improving the curriculum. He seemed a little uncertain about how he would fit into the new set-up and was uncomfortable about the prospect of being dis-empowered. However, he said that he would be willing to work with councilors to improve the dismal state of education.

Much discussion took place on whether teachers should be evaluated on a regular basis. There was no consensus, and the councilor present seemed to be unwilling to incur the wrath of those schoolteachers present by taking a stand on the issue. The overall consensus that emerged from the discussion was that there is a long way to go. However, it was really too difficult to make a fair assessment of the situation with such limited attendance, particularly on the part of the elected representatives.

The second skit was received well as it had been throughout, which is quite surprising. The Musalibat (Justice) Committee, which has been mentioned in the Local Government Ordinance as the local dispute resolution mechanism, was mentioned for the first time by a participant, who was neither a councilor nor from the administration. ${ }^{11}$ He pointed out that this committee should be the forum through which such cases should be dealt with. As it had just been announced on that day that the Public Safety Commissions would exercise a lot of power, he also suggested that forum. However, the point that was made repeatedly by all present was that local influentials still had a huge hold on how things were run, especially now that so many of them, or their agents, had been elected into local government. Many people were skeptical about the capacity of the Musalibat Committee to exercise power and reach decisions. Even the councilor present admitted that in the event that the local wadera had to be challenged, he was unable to say for sure whether all the union councilors would be willing to take a stand against him.

The point about the Musalihat Committee is important because it was the first time in the four sessions that it was mentioned. The person who brought it up was critical of the councilors saying that they should have taken an interest in finding out about the system, regardless of whether they were given training about it or not. The other point that the discussion raised was whether or not the Musalibut or other local committees assigned the task of resolving disputes would actually be able to do so. The alternative is dispute resolution by district level representatives,

${ }^{11}$ Government of Pakistan, (2001,pp:57-58). 
which then would mean that there really has been no devolution. Also, since District Nazims are normally from elite families, there was a feeling that there is even more chance than before that an ordinary citizen would be denied justice.

The point about the social taboo involved in this issue was raised as it was in earlier sessions. The police was targeted for being an unjust and feared institution. There was general scepticism about any of the existing institutions actually playing a positive role. Most people were also not convinced that the newly elected Councilors would have enough power to make an impact. Therefore, they emphasised the role of public-interest organisations and said that it was important that civil society alliances and networks be developed. In this regard, there was talk once again of involving journalists, bar associations, students, and other civil society groups. While there was agreement that issues should first be raised through the Councilors, there seemed to be more faith in these civil society networks. There was not much expectation that Councilors would work with civil society to tackle such problems.

The discussion was quite comprehensive, though unfortunately lacking the involvement of the administration. The positive element of this gathering was that civil society representatives seemed to be quite committed to generating pressure for change. If the Councilors can be seen as a means to carry forward this desire, and if the Councilors realise the potential of civil society in strengthening their hand, there may be room for optimism. However, it is clear that the influentials will make life difficult for anyone who challenges the status quo.

\section{Union Council, Abad Karkh (Rural). District Khuzdar ${ }^{12}$}

The session in Abad Karkh was perhaps the best of the five discussions up to this point in the fieldwork. This was in part because, for the first time, the police was represented by the local SHO. About 15 councilors and representatives of the Education Department were among the 30 people present. Unfortunately, there were only two women in the gathering, and while they were elected councilors, their input was very limited.

The discussion started off after the education skit (the skits were performed in Sindhi because the group came from Hyderabad, and also the local community was able to understand Sindhi). Most of those present, except the representatives of the Education Department, agreed that the situation presented was an accurate depiction of reality. They claimed that,

\footnotetext{
${ }^{12}$ Fieldwork conducted on August 30, 2001.
} 
in the past, the political appointments and interference of local politicians and influentials had ensured that problems, such as the one posed, could not be resolved because teachers not performing their duties could not be disciplined. They referred in particular to the tribal system in the area in which sardars (tribal chiefs) were very powerfu1. The Education Department was alleged to have been directly involved with sardars in the making of political appointments. In fact, it was established that very few cases of student-abuse by teachers were even taken to the Education Department, since there was really no point expecting any redress. It was also agreed that parents were often unsupportive of their children who were subjected to abuse.

In discussing the resolution of such problems under the new set-up, it was clear once again that the councilors present had little notion of what their real powers were and how they would go about addressing such problems. While they were keen to take whatever steps they could, there was a lack of direction and it seemed clear that action until now had been limited. The officials from the education department suggested that training had been offered by the government on how to take up such issues via the formation of local committees. Some councilors verified that they had received such training, but they did not think that this training was very effective. The women councilors present had even less of a notion of what they could do to address problems such as the one presented.

The second skit was received quite well considering that it was initially considered risky to present such a skit, with women actresses, in a conservative area. Nevertheless, those present did not react negatively, even though they were initially hesitant to acknowledge that anything of the sort happened in their communities. When finally there was a recognition that such incidents do occur, after the facilitator kept coming at the issue in different ways, those present felt that such matters should be handled within the community itself according to tribal custom.

In fact, the main response from the participants seemed to be that the best possible solution for a girl who had been raped would be for the rapist to marry her, although a couple of voices were raised about the wishes of the girl. Most felt this was reasonable, given the fact that the girl would otherwise be considered a social outcast. There was little indication that such cases were taken to the police and resolved. While the SHO present pointed out that under no circumstance would any leniency be given to perpetrators of such acts, he also pointed out that, on a number of occasions, cases filed with the police were retracted "voluntarily" because they involved influential people. 
There was little indication that the councilors felt empowered to really do anything about such cases, although they claimed that they would try and work from within the tribal set-up to ensure "justice" was meted out. They did not take the possibility of working with the police very seriously, as they clearly did not feel that this was an external problem. Some of the younger councilors were more weary of assuming that they could work within the tribal system to address such issues, but others were not at all willing to have such cases taken outside the communities. Overall, however, it was clear that this is an issue that was not likely to be impacted a great deal by a local government system being put in place. It was acknowledged that such problems would not disappear overnight. In fact, it was clear that there was little commitment from the councilors present to addressing the issue at any great length; in many ways they seemed to be protecting the tribal system. Women councilors offered very little input on this issue, in particular, and in general seemed quite uninformed.

\section{Union Council, Kaiitl (Urban), District Khuzdar ${ }^{13}$}

While the administration was not present, there were however a large number of councilors including the nazim of Tehsil Khuzdar. The two women present left shortly after the discussion began. There was a good representation of lawyers, teachers, doctors and other civil society groups. In all, there were about 40 participants. This was a very interesting session, and one that indicated the high level of political consciousness among the group of councilors that have been elected in the area. This political consciousness translated into a fair amount of cynicism and despondency about the capacity of the new system to actually be effective. From the outset, it was clear that the vast majority of councilors present were disillusioned about not having any distinct set of duties and the lack of clarity about their powers. Comments were made suggesting that the army was using the councilors as pawns, and that there was no real sincerity on the part of the government to devolve power. ${ }^{14}$

Prior to addressing the specific problem identified in the skit, there was a long general discussion about the nature of the new system and speculation about what the intention of the architects might be. Some, no doubt voicing a more widespread belief, referred to themselves as the Bteam of the army. The councilors said that they did not expect the bureaucracy to cooperate with them to address such issues because the bureaucracy had too much of a stake in the current set-up. The councilors

\footnotetext{
${ }^{13}$ Fieldwork conducted on August 31, 2001.

14 The Nazim of the Tehsil told us in private conversation that he was planning to visit the local Brigade Commander to find out about his powers, duties and responsibilities.
} 
were critical of not having received formal indication of how they would go about resolving such problems. There were a few voices that highlighted the need for councilors to come together, harness public support, and do whatever they could regardless of whether or not they will be empowered to truly address people's problems.

There was some mention of the role of parents, the importance of teacher training and monitoring. The relative effectiveness of private schools compared to government schooling was emphasised. Attention was drawn to the fact that private school teachers' salaries were lower than those of government school teachers, highlighting that low salaries was not a satisfactory excuse for the poor quality of education. Suggestions were made regarding how to operate government schools like private schools. However, the thinking among the councilors was that there was little chance that they could seriously change the status quo. Beyond this, there were few concrete suggestions about how to address the specific problem that was posed in the skit. The bureaucracy was criticised repeatedly for being opposed to the new councilors.

The second skit once again brought forth issues about the new system and the intentions of its architects. There was general agreement that the problem presented was more of a societal problem than one that was likely to be affected greatly by the form of government in place. There was considerable police bashing in this session. It was clear that the councilors, in particular, had little expectation that the police would do the right thing under any circumstance. They were very open about political heavyweights getting away with sexual crimes such as the one presented, and said that a tremendous change would need to take place for this hegemony to be challenged. They were also very clear that the community in question decided most cases of this kind in a jirga. They highlighted that it was the sardars who were more or less in control over such decisions. The one sardar present walked out during the course of this discussion.

The councilors reminded us repeatedly that they had won the elections despite the opposition of some of these sardars, and that this was therefore an indication of the type of commitment that they had. There were a lot of recriminations associated with a feeling of powerlessness under the new set-up. They were pessimistic about the possibility of the press, administration and others in civil society working with them. The notion of justice was again quite limited, with most present admitting that the girl who had been raped had little chance of leading a normal life. They therefore agreed that the best possible outcome for the girl would be that she get married off to the person who had committed the crime. 
There was such a sense of frustration that one of the councilors present demanded that we tell him what was going on and how this system was supposed to be run. After much insistence, he finally acknowledged our role as facilitators and conduits of information. This incident, however, was very indicative of the general feeling of all of those present.

\section{Union Council 33, (Urban). District, Mardan ${ }^{15}$}

The session was preceded by a two day period of great apprehension. The religious right is very influential in Mardan, and the intelligence agencies had made several trips to warn the organisers that they risked inciting the wrath of the clerics if they went ahead with the theatre. Eventually, it was decided that the event would take place, although parts of the skit were omitted because there was a fear that they might induce a negative reaction.

About 40 people participated in this session including, the local SHO, a number of teachers, lawyers, and journalists. A sizable number of councilors were present, including women, and overall it was a very good session. There was quick agreement after the first skit that it was very accurate, and that there were definitely problems with the education system. There were a variety of opinions expressed, including that the quality of education received was based on class background. Further, they added that there were deliberate attempts on the part of elite groups to ensure that common people did not receive a good education to limit their social mobility. Overall, those present agreed that the system was highly political, and that this was largely the reason that teachers were not compelled to provide quality education.

A number of teachers were defensive and suggested that there were many factors involved in the poor quality of education including little interest by parents in their children's schooling and low teachers' salaries which acted as a disincentive. Surprisingly, in response to this, a teacher pointed out that private schools paid teachers considerably less than government schools. There was agreement that the system needed an overhaul and that there needed to be special emphasis on education so that everyone, including students and parents themselves, made it a priority. One teacher mentioned that he had received training from the local education department and that had convinced him to stop treating his students badly. He urged other teachers to also learn from this.

\footnotetext{
${ }^{15}$ Urban fieldwork conducted on the morning of September 15, 2001 and rural fieldwork in the evening of the same day.
} 
The councilors present were not able to offer any concrete ideas on how to improve the system. As before, all of them claimed that they had little knowledge of the new system and they were not clear on what their powers were. There was a vague sense of a committee to be formed to take up the issue of education, but most of the councilors seemed to be indicating that their main role was simply to alert higher authorities, i.e. Tehsil and district officials, to the need to take notice of problems. There was little sense that any problem could actually be resolved at the union council level. There was also little faith in working with the education department itself.

The second skit was the real cause of concern among the organisers because they felt it was very risky in the local environment. Nevertheless, there was no ugly incident and there was some lively debate on the issue. The SHO present immediately pointed out that honour killing, under new legislation, is a capital crime. He claimed that the police acted on every case it was presented with. This claim was however disputed by most of those present, who generally agreed that very few crimes of this nature were reported. It was apparent that no one had much faith in the police, but, most people, including councilors, were not at all averse to working with the police to address such issues.

There was a lively debate about the nature of this crime, and whether it was considered a crime in the first place. The discussion essentially became a debate between the women and men present with the women suggesting that male attitudes had to change before such problems were ever going to be truly resolved. The men suggested that it was women who harboured the most biased opinions about women's roles in society, because women were most bound to marriage customs and other social biases. Nevertheless, there was consensus that the problem needed to be challenged in terms of societal attitudes at large.

When the discussion about potential means to address the problem began, the SHO painted a very positive picture of the police's role in such cases. He went on to say that honour killings (he used this name to identity this type of murder himself without being prompted) are to be treated as any other murder case. He refused to acknowledge that many such cases went unreported and said instead that the police would investigate such cases whether they were reported or not. There was little agreement with this among the larger group. However, councilors did say that they wanted to work with the police to take such cases up. Councilors in general seemed to think that such cases could be taken up on an individual basis if all councilors took them up together. Nevertheless, the debate mainly centred on how to change attitudes in society. 


\section{Union Council 70, (Rural). District Mardan}

There were no women present, although one later joined the proceedings, and the atmosphere was very intimidating. A DSP (deputy superintendent of police) was present, and belonged to the village in which the programmes was being held, but there were no officials representing the education department. A number of teachers were present along with a couple of lawyers. There were six winning candidates present among a total of 45 participants. There was some concern right before the event started about the appropriateness of females participating in the skits. However, there were assurances offered by the local organisers that there was no cause for concern and so the performances went ahead with the women covering everything up but their eyes. The education skit was well received - it was performed in Urdu rather than the local language (Pushto), but that was not a problem.

There was agreement, including among some educationists who were present, that this was an accurate depiction of the current situation. They suggested that the problem was multi-fold and included the lack of parental responsibility, as well as the lack of a culture of discipline. They also lamented that teacher's salaries were low and that therefore there was an incentive problem. There was little debate on these issues beyond these basic points.

The discussion about how the new system and councilors could help improve the situation raised many issues. It was quite clear that councilors were from affluent backgrounds, possibly part of a panel supported by the local Khans. It was clear that these councilors had as yet done very little. For the most part, they made reassuring promises in typical politician fashion. When repeatedly asked about how they would actually go about their business, with particular regard to the problem posed to them, there was very little they had to say.

They mentioned having received councilor training, but as was the case in other districts, there was not much indication that this amounted to much. There appeared to be a lack of commitment, and it seemed that most people viewed the local government plan to be a token exercise. The councilors seemed to view it as a way of cementing their established social standing in the area.

The second skit truly revealed the cultural and social realities of the area. There was a long, heated debate about religion and custom and how these factors did or did not contribute to the practice of honour killing. There seemed to be a consensus that a correct interpretation of Islam did 
not promote such practices. Almost all the participants acknowledged that honour killings were part of Pathan culture and custom. It was clear that most of those present accepted this as reality, and challenging this custom was never really considered an option.

At this point, a local woman social worker mentioned that this was a crime and that it needed to be treated as such. She also pointed out that it was society's responsibility as a whole to prevent such crimes from taking place. Her outspokenness was admirable considering the hostile environment. We learnt that this woman has been protesting honour killings for some time through a local organisation that she has formed. As a consequence, she was more or less an outcast from the community.

The DSP then spoke and said that new laws had been enacted that equated honour killings to a capital crime, and that this would be enforced. However, when asked about how often such crimes were reported or how often investigations were actually completed, the DSP admitted that very few cases were actually resolved. It was also established that even if cases did go to completion, very few families actually received justice.

When asked what could be done about the situation, a very cavalier attitude was predominant. Even those who cited Qur'anic references, indicating that the practice of honour killings was un-1slamic, were of the opinion that it would be pointless to try and challenge the Pathan custom. While they themselves acknowledged that this position was contradictory, since Pathans were Muslims, it was clear that this society does not presently have the will required to challenge the custom. At this point, councilors were not distinguishable from the rest of the audience, and, as in other areas where these sessions were held, social customs rather than the system of government was the issue.

\section{Summary and Recommendations}

We used theatre as a research tool to scrutinise the rules of business pertaining to the devolution of power to the grassroots level. Theatre was viewed as a valuable tool because, if well done, it could provoke discussion among the relevant stakeholders and get important feedback and suggestions. Thus, it would be possible to get insights into the shortcomings of the existing system from a grassroots perspective, and get suggestions for improvements. At a minimum, it would help in benchmarking and troubleshooting. 
The more ambitious specific objectives were as follows: Finding out how local bodies' powers, bureaucratic accountability and allocation of fiscal resources should be improved, as perceived at the grassroots level; Identifying where councilors and officials require training in the new operating environment; Generating greater interest in the local political processes; Generating greater involvement of voters and representatives in the new institutional framework; Getting insights into the problems of specific groups such as women and the very poor; and identifying areas for further exploration. In short, the objective was to have an impact on the local government rules of business and hence on the welfare and quality of life of the majority of Pakistan's population.

High quality theatre skits were conceptualised by the Interactive Resource Centre (IRC), and staged by extremely professional groups of local female and male actors trained by IRC. The skits pertained to problems with regard to the delivery of social services, specifically student-abuse by teachers in education, and the dispensation of justice, specifically rape (honour killing in Mardan). These were shown in four urban and four rural union councils, one in all the four main provinces of the country. The four districts visited were Gujrat in the Punjab, Hyderabad in Sindh, Khuzdar in Balochistan and Mardan in the NWFP. The fieldwork extended from August 5,2001 to September 15, 2001, in all cases alter the last phase of the local bodies elections. The fieldwork was facilitated by field support of DRCEP (Democratic Rights and Citizen's Education Programme) partners including the Institute of Development Studies and Practice (IDSP) in Balochistan, Sungi Development Foundation in the NWPP, South Asia PartnershipPakistan (SAP-Pk) in the Punjab and Pakistan Institute of Labour Education and Research (P1LER) in Sindh.

In both cases, we explored the issue of how the power distribution, at the grassroots level, between the state (local administration), local elites, local representatives and the citizens influences the outcome in the delivery of services. We focused on the union council level because that was the closest the devolution plan gets to grassroots empowerment. Stakeholders gathered for the viewing included elected local government representatives, district education and police officers, journalists, members of civil society groups and citizens. A number of findings emerged from the discussions that were facilitated after the viewing of the skits.

The skits, including that on sexual harassment, were viewed as highly representative of reality, very well received and provoked much discussion. The exercise was very effective as a barometer of the thinking of 
the new councilors, for benchmarking and for the identification of needs and suggestions from the grassroots. There were some universal findings and some specific to a particular urban or rural union council.

The starkest finding was the complete confusion that prevailed among both the councilors and local administration with regard to what their responsibilities and powers were under the new system. Some of the councilors had been exposed to rudimentary training, but there was no indication that it was helpful in this regard. Another finding, self-evident but nonetheless important, is that attitudes, and certainly a "feuda1 mindset," do not change overnight. Thus, in so far as the local elites (variously called sardurs, khans, waderas or jagirdars) captured the union council and higher tier seats for themselves and their panels, the power based traditional manner of doing things and getting things done will become accentuated. In all the union councils we visited, this is the reality both kinds of service delivery will have to contend with. ${ }^{16}$

In education, it was the political interference of the elites that determined who the teacher would be and provided immunity in case of poor delivery. In the cases of sexual harassment or honour killing, no one believed it would ever be possible to get justice if the feudal lord or his cronies were involved in the crime. Also, it was universally recognised that the real issues in such cases are prevailing social attitudes and in power structures and not changed local government structures per se. Thus, given existing norms, most cases of rape are not reported, and, even if they were, given existing power structures, there is little chance that there could be a settlement against the influentials.

The level of knowledge and awareness, particularly among the women councilors, was extremely low, with some exceptions. There was a vague sense that committees would be established to deal with the problems identified. Those who had received a smattering of training indicated that the problems would be reported to and resolved at the district level. Thus, it was not clear how, even at the union council level, they were going to be empowered to resolve local problems. However, the level of enthusiasm among the newly elected councilors was high. There was scepticism though on their part about whether the local administration would really respond to their initiatives to resolve

\footnotetext{
${ }^{16}$ For accounts of the importance of local power in determining the outcome of the 2001 local government elections, refer to Khan, Akhtar and Khan (2001). The two reports by Bari (2001) also incidentally touch on this issue.
} 
problems, notwithstanding their uncertainty about what powers they would have. They felt that the local administration had too much at stake in the existing corrupt system to allow real change. There was also scepticism on the part of the citizenry with regards to whether the new system would deliver anything. A large number viewed it as an opportunity for the influential to cement their social standing by becoming councilors. Finally, there was deep distrust of the police across the board and also doubts about the ability of councilors to work with them.

The more specific findings that pertained to the two cases are fairly well known. When confronted with the notion that the committees would resolve the problem of lax teachers who abused students, the participants immediately questioned why they would be any different from the ineffectual school management committees or parent teacher associations currently in place. Even so, one finding was that councilors wanted to bypass the educational establishment, which was viewed to be part of the problem, to resolve problems at the community level working with parents and teachers. Direct action by parents as such was not approved, although it was conceded that approaching the educational establishments does not yield results.

Teachers in the discussion groups were naturally defensive and blamed their low salaries and the lack of respect accorded to them by society for their low level of commitment. They also blamed the lack of interest parents had in the education of their children. However, participants were quick to point out that private sector teachers get paid much less and deliver much better education.

Only one citizen, and no councilor, knew about the Muslihat Committee as an alternative dispute resolution mechanism. However, the general feeling was that given the power of the local elites, little would be achieved in terms of the dispensation of justice to the poor via this committee or the public safety committee. In fact, it was thought that there might be less justice than before given that the majority of Nazims are from relatively influential families. One women councilor expressed the view that the danger of opposing a local influential is much too great, and others echoed this view.

It is fairly clear that, particularly in the case of sexual harassment, rape or honour killings, devolution, without far reaching structural and social reforms that address imbalances in power and 
72 The Lahore Journal of Economics, Vol.7, No.1

social norms, would not improve service delivery for the poor. In this regard, land, civil service, police and judicial reforms and, a more enlightened educational curricula are vital. As things stand, much more and much more effective training is needed to clarify the responsibilities and powers of newly elected representatives. Finally, while we found theatre to be an effective research tool, we sensed that it is an even more effective awareness raising and training tool and should be utilised and taken to scale. 
Shahrukh Rafi Khan and Aasim Sajjad Akhtar 73

\section{References}

Bari, F., 2001, "Local Government Election" December 2000-(Phase-I) Pattan Development Organisation, Islamabad.

Government of Pakistan, 2001, "The SBNP Local Government (Mode1) Ordinance 2001” National Reconstruction Bureau, Islamabad.

Khan, S. R., 2001, Khan, S. R., "Promoting Democratic Governance: the Case of Pakistan," European Journal of Development Research, forthcoming. Vo1. 13, No. 2.

Khan, S. R., A. S. Akhtar and F. S. Khan, 2001, "Investigating the Importance of Landed Power and other Determinants of Local Body Election Outcomes," in ed. M. Waseem Electoral Reforms Islamabad: Friedrich Ebert Stiftung, forthcoming. 